\title{
Effects of snow ratio on annual runoff within the Budyko framework
}

\author{
D. Zhang, Z. Cong, G. Ni, D. Yang, and S. Hu \\ State Key Laboratory of Hydroscience and Engineering, Department of Hydraulic Engineering, Tsinghua University, \\ Beijing 10084, China
}

Correspondence to: Z. Cong (congzht@ $@$ tsinghua.edu.cn)

Received: 30 December 2014 - Published in Hydrol. Earth Syst. Sci. Discuss.: 22 January 2015

Revised: 25 March 2015 - Accepted: 29 March 2015 - Published: 24 April 2015

\begin{abstract}
A warmer climate may lead to less precipitation falling as snow in cold seasons. Such a switch in the state of precipitation not only alters temporal distribution of intra-annual runoff but also tends to yield less total annual runoff. Long-term water balance for 282 catchments across China is investigated, showing that a decreasing snow ratio reduces annual runoff for a given total precipitation. Within the Budyko framework, we develop an equation to quantify the relationship between snow ratio and annual runoff from a water-energy balance viewpoint. Based on the proposed equation, attribution of runoff change during the past several decades and possible runoff change induced by projected snow ratio change using climate experiment outputs archived in the Coupled Model Intercomparison Project Phase 5 (CMIP5) are analyzed. Results indicate that annual runoff in northwestern mountainous and northern highlatitude areas are sensitive to snow ratio change. The proposed model is applicable to other catchments easily and quantitatively for analyzing the effects of possible change in snow ratio on available water resources and evaluating the vulnerability of catchments to climate change.
\end{abstract}

\section{Introduction}

More than one-sixth of the world's population lives in catchments with snowmelt-dominated runoff (Barnett et al., 2005), and thus change in snowfall may exert a great influence over available water resources in these regions. In a warmer climate, the rising temperature may decrease the precipitation falling as snow in cold seasons. A decrease in snowfall amount and an increase in temperature can lead to an earlier spring peak river runoff and a reduction in summer-autumn runoff for a given total annual precipita- tion (Stewart et al., 2005; Godsey et al., 2014). Therefore, the change in the state of precipitation (rainfall or snow) induced by global warming would alter the temporal distribution of intra-annual runoff, thereby increasing the possibility of spring flood disasters (Allamano et al., 2009) and summer water supply crises in relevant regions. Although the possible events can have catastrophic impacts on those snowdominated basins, these impacts can be mitigated where existing reservoirs possess adequate storage capacity to buffer the shift in runoff timing (Vörösmarty et al., 1997; Payne et al., 2004). To date, however, little work has been done to investigate the impact and mechanism of this shift in the state of precipitation on mean annual runoff which is a key factor that controls the available freshwater resources for domestic and agricultural needs. Berghuijs et al. (2014) conducted a preliminary analysis using the Model Parameter Estimation Experiment (MOPEX) data set and found that a higher snowfall fraction is statistically associated with increased annual runoff at pristine catchments. They also pointed out that mechanistic understanding of this phenomenon is still lacking. Inspired by Berghuijs et al. (2014), we aim to understand and quantify the relationship between the snow ratio of precipitation falling as snow to total precipitation and mean annual runoff, as well as assess the hydrologic response to snow ratio variation induced by climate change in this study.

In order to address the problem, adopting a distributed hydrological model coupled with global circulation model (GCM) projections and calibrated with observed data may be a way (Cayan et al., 2008; Huss et al., 2008). However, large numbers of parameters and the site-specific nature of distributed models limit us to clarify the dominant factors affecting the connection between snow ratio and mean annual runoff. Furthermore, the distributed model may perform well over short timescales, but large knowledge gaps still remain 


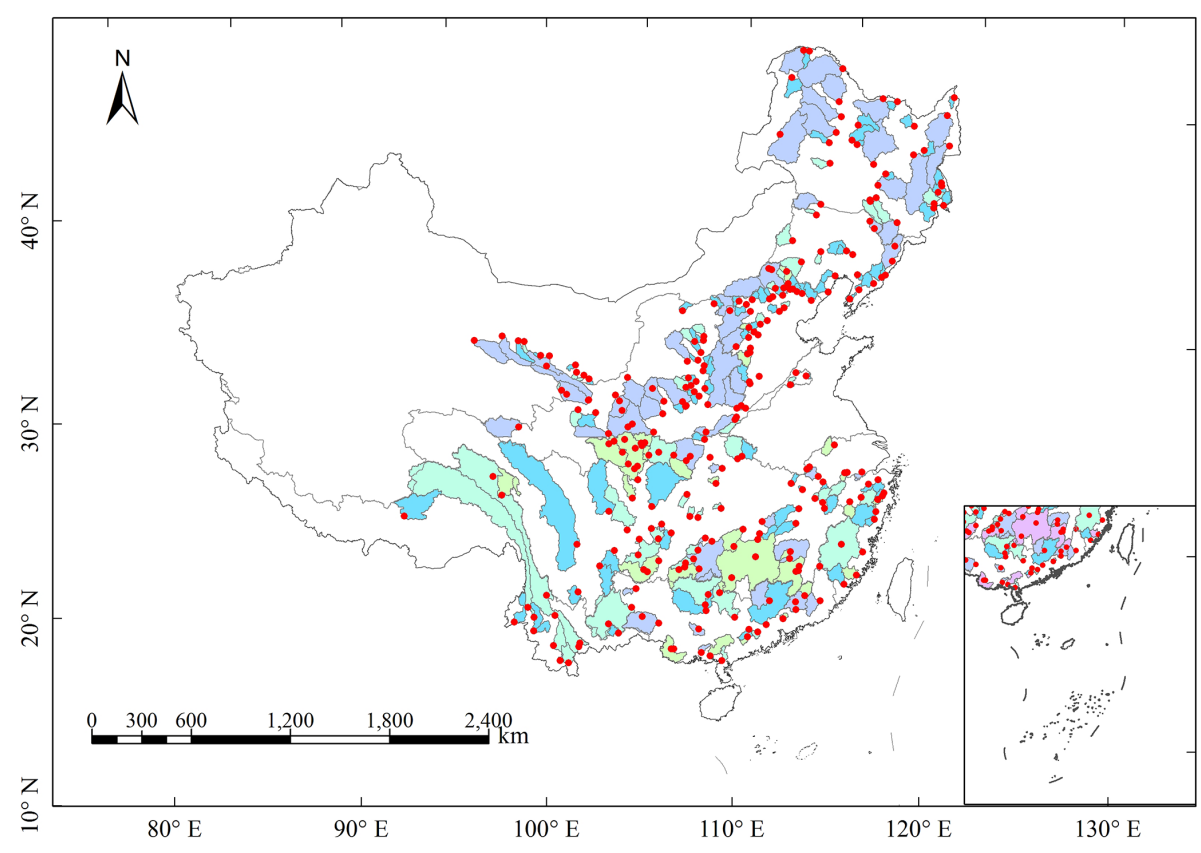

Figure 1. The location of the studied catchments. Red points represent catchment runoff gauge stations.

at multi-annual timescale that impede the pursuit of better understanding the effect of snow ratio on mean annual runoff. Meanwhile, it can be a very tedious exercise when quantifying the impact of snow ratio change on the mean annual runoff by applying a detailed hydrologic model to hundreds of catchments.

Low-dimensional models may provide us with an alternative tool to isolate the key component of the relationship between the above two variables. Budyko (1974) introduced a simplified analytical framework to quantify the long-term average hydrologic partitioning between runoff and evapotranspiration at catchment scale. Within this framework, the actual evapotranspiration $(E)$ is determined, to the first order, by available energy and available water which are measured as potential evapotranspiration $\left(E_{\mathrm{p}}\right)$ and precipitation $(P)$, respectively. Subsequently, much effort (Fu, 1981; Choudhury, 1999; Yang et al., 2008) has focused on theoretical and empirical development of the framework by introducing an additional parameter accounting for local landscape characteristics (Yang et al., 2009) or seasonality of climate forcing (Feng et al., 2012). This simple framework captures the main features of the water-energy balance and is widely employed to evaluate the hydrologic response to climate change and human activities (Roderick and Farquhar, 2011; Wang and Hejazi, 2011). When addressing the influence of snow ratio on the mean annual runoff, the water-energy balance is also the key point which needs to be clarified. Thus, it is a possible way to investigate the influence of snow ratio on mean annual runoff in the context of the Budyko framework.

Here, we study the effects of snow on the mean annual runoff by analyzing the long-term observed records from catchments across China. A theoretical tool is proposed to help us have a deeper understanding of the role of snow on the mean annual runoff quantitatively. In addition, the contributions of changes in the snow ratio to the variations in annual runoff during the past several decades and possible changes in annual runoff under projected climate scenario are also presented. Such studies are expected to present important implications for future water management strategy when global warming is considered.

\section{Data sources}

The daily meteorological data, including precipitation, temperature, relative humidity, wind speed and sunshine hours were collected at 743 national meteorological stations during 1961-2010 from the China Meteorological Administration. In addition, daily solar radiation was collected from 118 stations during the period 1961-2010. Meanwhile, monthly runoff data of 282 catchments across China were collected. These catchments were selected based on the length of records exceeding 25 years and all observed points being within the supply and demand limits of the framework. Furthermore, there is relatively low direct influence of human activities such as, irrigation, damming, and water diversion on the catchments. The areas of these catchments vary from 372 to $142963 \mathrm{~km}^{2}$ and these catchments cover a sizable portion of land area within China as shown in Fig. 1. The catchment average slope was calculated from the HYDRO1k data sets, developed by the US Geological Survey's (USGS) Earth Resources Observation and Science (EROS) Data Cen- 
ter, at a resolution of $1 \mathrm{~km}$. (available at http://eros.usgs.gov/ elevation-products).

Because the precipitation type has not been available at any of the meteorological stations since 1980, the empirical relationship evaluated for the Chinese territory to discriminate precipitation types is called for. The empirical discrimination scheme (Ding et al., 2014) derived from more than 400000 samples collected from different climate regimes and elevations across China from 1951 to 1979 was adopted. The precipitation is categorized according to

type $= \begin{cases}\text { snow, } & T_{\mathrm{w}} \leq T_{1} \\ \text { sleet, } & T_{1} \leq T_{\mathrm{w}} \leq T_{2}, \\ \text { rain, } & T_{\mathrm{w}} \geq T_{2}\end{cases}$

where $T_{\mathrm{w}}$ is daily mean wet-bulb temperature, a function of air temperature, relative humidity and air pressure. $T_{1}$ and $T_{2}$ are two threshold temperatures which can be empirically parameterized by relative humidity and elevation based on the observations. According to this discrimination scheme, if a precipitation event was judged as snow or sleet, the corresponding precipitation quantity was counted in the annual snowfall amount.

To obtain the average daily climate forcing in each catchment, a $10 \mathrm{~km}$ grid data across the China was interpolated from the observations of all meteorological stations by angular distance-weighted interpolation, and then catchment values were calculated by averaging values of grids covering the analyzed catchments. The interpolated grid temperature was modified by its elevation. Daily $E_{\mathrm{p}}$ was calculated based on the Penman-FAO equation (Allen et al., 1998) using grid data with consideration of the corresponding land use type. And the $E_{\mathrm{p}}$ of grids which are water and non-water were calculated using Eqs. (2) and (3), respectively.

$E_{\mathrm{p}}=\frac{\Delta}{\Delta+\gamma} \frac{R_{\mathrm{n}}-G}{\lambda}+\frac{\Delta}{\Delta+\gamma} \frac{6.43\left(1+0.536 U_{2}\right)\left(e_{\mathrm{s}}-e_{\mathrm{a}}\right)}{\lambda}$,
$E_{\mathrm{p}}=0.408 \frac{\Delta}{\Delta+\gamma^{*}}\left(R_{\mathrm{n}}-G\right)+\frac{\gamma}{\Delta+\gamma^{*}} \frac{900}{T+273} U_{2}\left(e_{\mathrm{s}}-e_{\mathrm{a}}\right)$,

where $T$ is daily average air temperature $\left[{ }^{\circ} \mathrm{C}\right]$ and $\Delta$ is the slope of the saturated vapor pressure versus $T$ curve $\left[\mathrm{kPa}{ }^{\circ} \mathrm{C}^{-1}\right] ; U_{2}$ is the wind speed at $2 \mathrm{~m}$ above ground $\left[\mathrm{m} \mathrm{s}^{-1}\right] ; e_{\mathrm{S}}$ is the saturated vapor pressure $[\mathrm{kPa}] ; e_{a}$ is the actual vapor pressure $[\mathrm{kPa}] ; R_{\mathrm{n}}$ and $G$ are the net radiation and ground heat flux, respectively [MJ m$\left.{ }^{-2} \mathrm{~d}^{-1}\right] ; \lambda$ is the latent heat of vaporization of water $\left[\mathrm{J} \mathrm{g}^{-1}\right]$ and $\gamma$ is the psychometric constant $\left[\mathrm{kPa}^{\circ} \mathrm{C}^{-1}\right], \gamma^{*}=\gamma\left(1+0.34 U_{2}\right)$.

The daily climate variables were aggregated to annual values for all catchments. The snow ratio $\left(r_{\mathrm{s}}\right)$ was calculated as the ratio of mean annual snowfall amount to mean annual precipitation, which can eliminate the influence of phase difference originating from the snow accumulation and melting in different years.

The monthly Global Inventory Modeling and Mapping Studies (GIMMS) normalized difference vegetation index
(NDVI) from 1982 to 2006 with $8 \mathrm{~km}$ resolution was collected from the Advanced Very High Resolution Radiometer (AVHRR) sensor (Buermann et al., 2002). Likewise, longterm average annual NDVI value for each catchment was calculated from the data set and the corresponding vegetation coverage $(M)$ was estimated following Gutman and Ignatov (1998):

$M=\frac{\mathrm{NDVI}-\mathrm{NDVI}_{\min }}{\mathrm{NDVI}_{\max }-\mathrm{NDVI}_{\min }}$,

where $\mathrm{NDVI}_{\max }$ and $\mathrm{NDVI}_{\min }$ are the NDVI signals from dense green vegetation and bare soil, which were chosen to be 0.80 and 0.05 , respectively (Yang et al., 2009).

The future climate forcing, monthly precipitation, temperature and snowfall outputs of all the available experiments from two representative concentration pathways (RCPs) archived in the Coupled Model Intercomparison Project Phase 5 (CMIP5) (Taylor et al., 2012) were extracted (38 GCMs for RCP4.5; 40 GCMs for RCP8.5, as shown in Table 1). For each GCM and each RCP, the precipitation, temperature and snowfall outputs at the archived spatial resolution were regridded to $0.5^{\circ} \times 0.5^{\circ}$ grid cells. For each catchment, the monthly areal average precipitation, temperature and snowfall from 2050 to 2099 were calculated from above model outputs. Monthly $E_{\mathrm{p}}$ was computed using the Hamon's equation (Hamon, 1961) as

$E_{\mathrm{p}}=\alpha \cdot d \cdot D^{2} \cdot \rho_{\mathrm{w}}$,

where $d$ is the number of days in a month, $D$ is the mean monthly hours of daylight in units of $12 \mathrm{~h}$, $\rho_{\mathrm{w}}=0.0495 e^{0.062 T}$ is a saturated water vapor density and $T$ is the monthly mean temperature $\left[{ }^{\circ} \mathrm{C}\right] . \alpha$, the adjustment factor, was calibrated via minimizing the difference between the two mean annual $E_{\mathrm{p}}$ values (2000-2010) obtained by the Penman-FAO and Hamon's equation for each catchment. The projected monthly precipitation, snowfall and potential evapotranspiration were aggregated to annual values for 2050-2099.

\section{Methodology}

\subsection{Inclusion of snow ratio in the Budyko framework}

At multi-decade timescales, neglecting the catchment groundwater or glacial storage change, mean annual actual $E$ is estimated as the residual of annual precipitation minus runoff $(Q)$. On the other hand, $E$ can be given by a function of available energy $\left(E_{\mathrm{p}}\right)$ and available water $(P)$ for evapotranspiration, proposed by Budyko (1974):

$$
1-\frac{Q}{P}=\sqrt{\frac{E_{\mathrm{p}}}{P}\left[1-\exp \left(-\frac{E_{\mathrm{p}}}{P}\right)\right] \tanh \left(\frac{1}{E_{\mathrm{p}} / P}\right)} .
$$

Other Budyko-type curves were developed for describing catchment long-term water balance, by introducing a unique 
Table 1. Overview of selected GCMs used in climate impact assessment. More details of the models, modeling centers and meaning of the ensemble codes can be found at http://cmip-pcmdi.llnl.gov/cmip5/availability.html.

\begin{tabular}{|c|c|c|c|c|c|}
\hline \multicolumn{3}{|c|}{$\mathrm{RCP} 4.5$} & \multicolumn{3}{|c|}{ RCP8.5 } \\
\hline No. & Model & Ensemble & No. & Model & Ensemble \\
\hline 1 & ACCESS1.0 & rli1p1 & 1 & ACCESS1.0 & rlilp1 \\
\hline 2 & ACCESS1.3 & rli1p1 & 2 & ACCESS1.3 & rlilp1 \\
\hline 3 & BCC-CSM1-1 & rli1p1 & 3 & BCC-CSM1-1 & rlilp1 \\
\hline 4 & BCC-CSM1-1-m & rli1p1 & 4 & BCC-CSM1-1-m & rli1p1 \\
\hline 5 & BNU-ESM & rli1p1 & 5 & BNU-ESM & rli1p1 \\
\hline 6 & CCSM4 & rli1p1 & 6 & CANESM2 & rlilp1 \\
\hline 7 & CESM1-BGC & rli1p1 & 7 & CCSM4 & rli1p1 \\
\hline 8 & CESM1-CAM5 & rli1p1 & 8 & CESM1-BGC & rli1p1 \\
\hline 9 & CESM1-WACCM & r1i2p1 & 9 & CESM1-CAM5 & r1ilp1 \\
\hline 10 & CMCC-CM & rli1p1 & 10 & CESM1-WACCM & r1i2p1 \\
\hline 11 & CMCC-CMS & rli1p1 & 11 & CMCC-CESM & rlilp1 \\
\hline 12 & CNRM-CM5 & rli1p1 & 12 & CMCC-CM & rlilp1 \\
\hline 13 & CSIRO-Mk3-6-0 & rli1p1 & 13 & CMCC-CMS & r1ilp1 \\
\hline 14 & CANESM2 & rli1p1 & 14 & CNRM-CM5 & rli1p1 \\
\hline 15 & EC-EARTH & r5ilp1 & 15 & CSIRO-Mk3-6-0 & rli1p1 \\
\hline 16 & FGOALS-g2 & r1i1p1 & 16 & EC-EARTH & r2i1p1 \\
\hline 17 & FIO-ESM & rli1p1 & 17 & FGOALS-g2 & rlilp1 \\
\hline 18 & GFDL-CM3 & rli1p1 & 18 & FIO-ESM & rli1p1 \\
\hline 19 & GFDL-ESM2G & rli1p1 & 19 & GFDL-CM3 & rlilp1 \\
\hline 20 & GFDL-ESM2M & r1i1p1 & 20 & GFDL-ESM2G & rli1p1 \\
\hline 21 & GISS-E2-H & rli1p1 & 21 & GFDL-ESM2M & r1i1p1 \\
\hline 22 & GISS-E2-H-CC & rli1p1 & 22 & GISS-E2-H & rlilp1 \\
\hline 23 & GISS-E2-R & rli1p1 & 23 & GISS-E2-H-CC & rlilp1 \\
\hline 24 & GISS-E2-R-CC & rli1p1 & 24 & GISS-E2-R & rli1p1 \\
\hline 25 & HadGEM2-CC & rli1p1 & 25 & GISS-E2-R-CC & r1i1p1 \\
\hline 26 & HadGEM2-ES & rli1p1 & 26 & HadGEM2-CC & r1i1p1 \\
\hline 27 & INMCM4 & r1i1p1 & 27 & HadGEM2-ES & rlilp1 \\
\hline 28 & IPSL-CM5A-LR & rli1p1 & 28 & INMCM4 & rli1p1 \\
\hline 29 & IPSL-CM5A-MR & rli1p1 & 29 & IPSL-CM5A-LR & rlilp1 \\
\hline 30 & IPSL-CM5B-LR & rli1p1 & 30 & IPSL-CM5A-MR & r1i1p1 \\
\hline 31 & MIROC-ESM & rli1p1 & 31 & IPSL-CM5B-LR & rlilp1 \\
\hline 32 & MIROC-ESM-CHEM & r1i1p1 & 32 & MIROC5 & rlilp1 \\
\hline 33 & MIROC5 & rli1p1 & 33 & MIROC-ESM & rlilp1 \\
\hline 34 & MPI-ESM-LR & rli1p1 & 34 & MIROC-ESM-CHEM & rlilp1 \\
\hline 35 & MPI-ESM-MR & rli1p1 & 35 & MPI-ESM-LR & rlilp1 \\
\hline 36 & MRI-CGCM3 & rli1p1 & 36 & MPI-ESM-MR & r1i1p1 \\
\hline 37 & NorESM1-M & rli1p1 & 37 & MRI-CGCM3 & rli1p1 \\
\hline \multirow[t]{3}{*}{38} & NorESM1-ME & rli1p1 & 38 & MRI-ESM1 & rli1p1 \\
\hline & & & 39 & NorESM1-M & rlilp1 \\
\hline & & & 40 & NorESM1-ME & r1ilp1 \\
\hline
\end{tabular}

parameter to assess differences among catchments (Fu, 1981; Choudhury, 1999; Zhang et al., 2001; Wang and Tang, 2014). Among them, Yang et al. (2008) provided a theoretical solution to the mean annual water-energy balance equation under general conditions through dimensional analysis and mathematic reasoning, which shares the same functional form with Choudhury's equation
$1-\frac{Q}{P}=\left[1+\left(\frac{E_{\mathrm{p}}}{P}\right)^{-n}\right]^{-1 / n}$,

where $n$ is a synthesis parameter which represents the effects of catchment factors (i.e., vegetation type and coverage, soil type and topography) on the precipitation partitioning, referred to as the specific catchment parameter herein. As shown in Fig. 2, the relationship between mean annual runoff index $(Q / P)$ and dryness index $\left(E_{\mathrm{p}} / P\right)$ is depicted. 


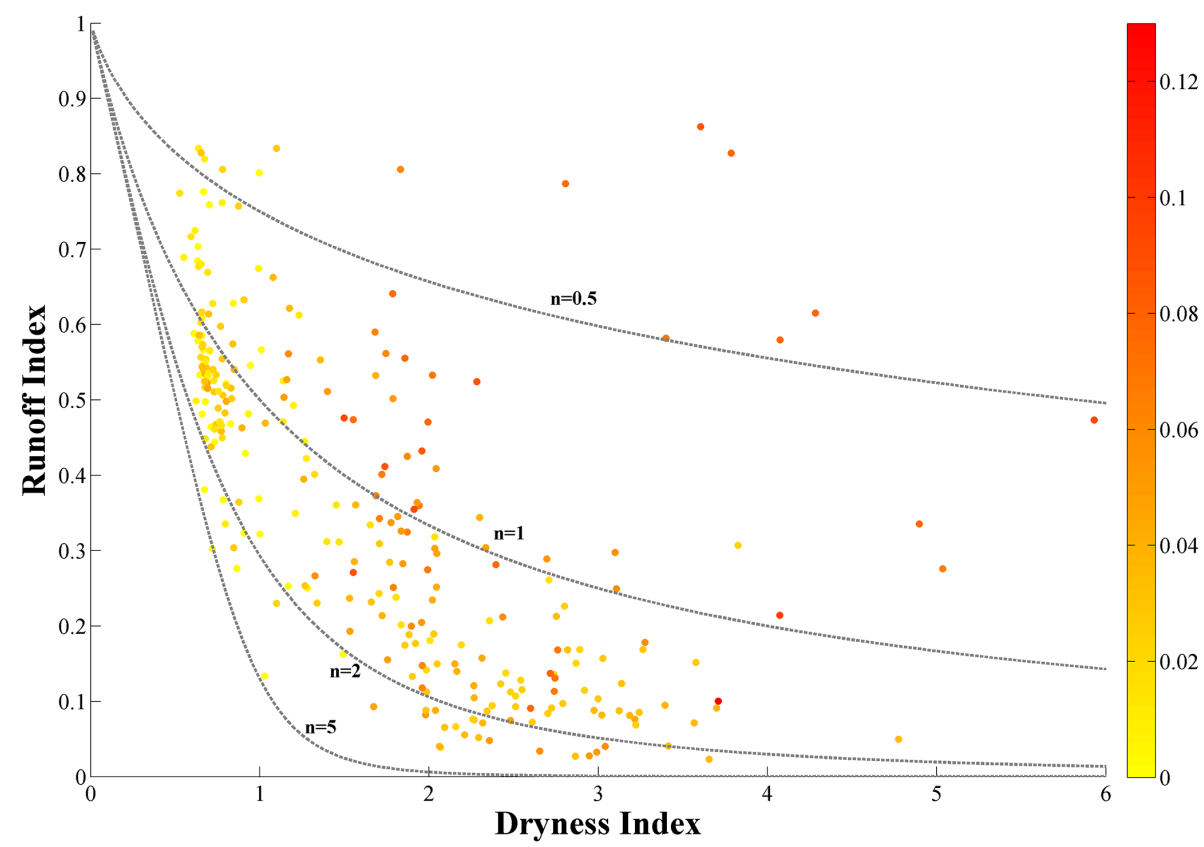

Figure 2. The 282 long-term climatological water budget observations in China. Each point represents a catchment. The color refers to the snow ratio. Dashed lines are derived from Eq. (7) with different $n$ values.

A larger value of $n$ is associated with a lower runoff index given the same dryness index.

When snowfall is considered, there are some differences in energy and water terms involved in Eq. (7). For evapotranspiration capacity, it should be noted that part of the available energy which needs to be taken away to melt the snowfall compared with "paired catchment" where other conditions are the same but all precipitation falls as rainfall. Meanwhile, little sublimation and runoff are observed during snow accumulation season (Anderson, 1968; Dewalle and Meiman, 1971; Weller and Holmgren, 1974). The snowfall needs to be transferred into liquid phase before it can participate in the hydrological cycle. The melting energy $R_{\mathrm{m}}$ required to convert snowfall to the reference state $\left(0^{\circ} \mathrm{C}\right.$ liquid phase $)$ reads

$R_{\mathrm{m}}=\rho_{\mathrm{w}} W\left(h_{\mathrm{f}}+C_{\mathrm{i}} \overline{\Delta T}\right)$,

where $\rho_{\mathrm{w}}$ is the density of water $\left[1000 \mathrm{~kg} \mathrm{~m}^{-3}\right] ; W$ is snow water equivalence [m], i.e., snowfall amount $\left(r_{\mathrm{s}} \cdot P\right) ; h_{\mathrm{f}}$ is the latent heat of fusion [335 kJ kg$\left.{ }^{-1}\right] . C_{\mathrm{i}} \overline{\Delta T}$ represents the energy needed in snow warming phase during which the average accumulated snow temperature increases until the snowpack is isothermal at $0^{\circ} \mathrm{C}$ where $C_{\mathrm{i}}$ is the specific heat of ice $\left[2.1 \mathrm{~kJ} \mathrm{~kg}^{-1}{ }^{\circ} \mathrm{C}^{-1}\right]$ and $\overline{\Delta T}$ average negative snow surface temperature, order of $10^{\circ} \mathrm{C}$.

Thus, the effective energy available for evapotranspiration $E_{\mathrm{p}}^{\mathrm{e}}$ is the difference between $E_{\mathrm{p}}$ and melting heat equivalence $R_{\mathrm{m}} / L$, where $L$ is latent heat of evaporation $\left[2500 \mathrm{~kJ} \mathrm{~kg}^{-1}\right]$. After a rough algebraic computation, $E_{\mathrm{p}}^{\mathrm{e}}$ reads
$E_{\mathrm{p}}^{\mathrm{e}}=E_{\mathrm{p}}-R_{\mathrm{m}} / L=E_{\mathrm{p}}-0.14 r_{\mathrm{s}} \cdot P$.

In melting season, the magnitude of sensible heat is several times larger than latent heat (Dingman, 2002), implying that only a small part of snow is evaporated or sublimated. For example, according to the energy budget during the accumulation and melt periods for six seasons (1968-1973) at the Danwille site, VT, USA (Anderson, 1976), the average turbulent exchange of latent heat in each season are $1160 \mathrm{cal} \mathrm{cm}^{-2}$, equivalent to $1.7 \mathrm{~cm}$ vaporized water. Compared with the maximum snow depth of $72 \mathrm{~cm}$ in that location, the evaporation of snowfall is very small.

Furthermore, the concrete frozen ground is most commonly found in open land and sometimes in forested land (Pierce et al., 1958; Fahey and Lang, 1975), which makes the melting water infiltration difficultly. Given that the frozen ground has extremely low permeability, the surface flow is preferred during the snow melting period (Dunne and Black, 1971); moreover, the melting snowfall accumulates to form a basal saturated zone through which water drains to the stream (Anderson, 1976). Therefore, it is acceptable to assume that melting snow water flows away through channels without evaporation loss. As a consequence, the effective available water for evapotranspiration is annual rainfall $\left(1-r_{\mathrm{s}}\right) \cdot P$, rather than total precipitation $P$.

The water-energy balance in form of Eq. (7) with consideration of snow can be rewritten as follows: 


$$
\frac{P-Q}{\left(1-r_{\mathrm{s}}\right) \cdot P}=\left[1+\left(\frac{E_{\mathrm{p}}}{\left(1-r_{\mathrm{s}}\right) \cdot P}-\frac{0.14 r_{\mathrm{s}}}{1-r_{\mathrm{s}}}\right)^{-n^{\prime}}\right]^{-1 / n^{\prime}} .
$$

Normally, the snow ratio $r_{\mathrm{s}}$ is an order of 0.1 , with a median value of 0.03 among studied catchments in Fig. 1 (median value of 0.09 in the MOPEX data set used by Berghuijs et al., 2014). The energy correction term $0.14 r_{\mathrm{s}} /\left(1-r_{\mathrm{s}}\right)$ in Eq. (10) is about an order of 0.01 , and can be neglected compared with the revised dryness index $E_{\mathrm{p}} /\left[\left(1-r_{\mathrm{s}}\right) \cdot P\right]$ which is an order of 1 . Therefore, with little loss of accuracy, the simplified Eq. (10) can be written as

$$
1-\frac{Q}{P}=\left[\left(1-r_{\mathrm{s}}\right)^{-n^{\prime}}+\left(\frac{E_{\mathrm{p}}}{P}\right)^{-n^{\prime}}\right]^{-1 / n^{\prime}} .
$$

\subsection{Attribution of runoff change}

Given the inclusion of snow ratio, Eq. (11) can be used to analyze long-term water balance of catchment where snow plays a considerable role in hydrological process. Furthermore, this will provide a theoretical tool to attribute the mean annual runoff change to climate variability, especially the snow ratio change, and land use/cover change. An additional assumption that the runoff change is from one steady state to another without any transient changes is introduced here. We reorganize Eq. (11) and differentiate it to calculate change in $Q$ due to changes in climate factors $\left(P, E_{\mathrm{p}}, r_{\mathrm{s}}\right)$ and catchment characteristic $\left(n^{\prime}\right)$.

$$
Q=P-\left[P^{-n^{\prime}}\left(1-r_{\mathrm{s}}\right)^{-n^{\prime}}+E_{\mathrm{p}}^{-n^{\prime}}\right]^{-1 / n^{\prime}}
$$

To the first order,

$\mathrm{d} Q=\frac{\partial Q}{\partial P} \mathrm{~d} P+\frac{\partial Q}{\partial E_{\mathrm{p}}} \mathrm{d} E_{\mathrm{p}}+\frac{\partial Q}{\partial r_{\mathrm{s}}} \mathrm{d} r_{\mathrm{s}}+\frac{\partial Q}{\partial n^{\prime}} \mathrm{d} n^{\prime}$,

where

$$
\begin{aligned}
& \frac{\partial Q}{\partial P}=1-\frac{P-Q}{P} \frac{E_{\mathrm{p}}^{n^{\prime}}}{\left[P\left(1-r_{\mathrm{s}}\right)\right]^{n^{\prime}}+E_{\mathrm{p}}^{n^{\prime}}}, \\
& \frac{\partial Q}{\partial E_{\mathrm{p}}}=-\frac{P-Q}{E_{\mathrm{p}}} \frac{\left[P\left(1-r_{\mathrm{s}}\right)\right]^{n^{\prime}}}{\left[P\left(1-r_{\mathrm{s}}\right)\right]^{n^{\prime}}+E_{\mathrm{p}}^{n^{\prime}}}, \\
& \frac{\partial Q}{\partial r_{\mathrm{s}}}=\frac{P-Q}{1-r_{\mathrm{s}}} \frac{E_{\mathrm{p}}^{n^{\prime}}}{\left[P\left(1-r_{\mathrm{s}}\right)\right]^{n^{\prime}}+E_{\mathrm{p}}^{n^{\prime}}}, \\
& \frac{\partial Q}{\partial n^{\prime}}=-\frac{P-Q}{n^{\prime}}\left(\frac{\ln \left[P^{n^{\prime}}\left(1-r_{\mathrm{s}}\right)^{n^{\prime}}+E_{\mathrm{p}}^{n^{\prime}}\right]}{n^{\prime}}\right. \\
& \left.-\frac{\left[P\left(1-r_{\mathrm{s}}\right)\right]^{n^{\prime}} \ln \left[P\left(1-r_{\mathrm{s}}\right)\right]+E_{\mathrm{p}}^{n^{\prime}} \ln \left(E_{\mathrm{p}}\right)}{\left[P\left(1-r_{\mathrm{s}}\right)\right]^{n^{\prime}}+E_{\mathrm{p}}^{n^{\prime}}}\right) .
\end{aligned}
$$

With Eq. (13), we can estimate the change in runoff between pre- and post-period due to variations of precipitation, potential evapotranspiration, snow ratio and catchment parameter, respectively. Specifically, relative contribution of snow ratio variation to annual runoff change, $\eta_{r_{\mathrm{s}}}$, is defined as

$\eta_{r_{\mathrm{s}}}=\frac{\Delta Q_{r_{\mathrm{s}}}}{\Delta Q} \cdot \frac{|\Delta Q|}{Q_{1}}=\operatorname{sgn}(\Delta Q) \cdot \frac{\frac{\partial Q}{\partial r_{\mathrm{s}}} \Delta r_{\mathrm{s}}}{Q_{1}}$,

where $\Delta Q_{r_{\mathrm{s}}}=\frac{\partial Q}{\partial r_{\mathrm{s}}} \Delta r_{\mathrm{s}} ; \Delta Q=Q_{2}-Q_{1}$ and $\Delta r_{\mathrm{s}}=r_{\mathrm{s}_{2}}-r_{\mathrm{s}_{1}}$ represent difference between post- and pre-period recorded mean annual runoff and snow ratio, respectively; $\Delta n^{\prime}$ represents change in land cover and can be calculated using the mean annual $P$ and $E_{\mathrm{p}}$, as well as $r_{\mathrm{s}}$ for each sub-period by Eq. (11).

\section{Results and discussion}

\subsection{Effect of snow ratio on runoff}

$Q / P$ of the 282 catchments is plotted in Fig. 2 as a function of $E_{\mathrm{p}} / P$. Each point represents a mean annual record for one basin with different a colors indicating the various snow ratios. The dashed lines are derived from Eq. (7) with different specific catchment parameter, by neglecting changes in catchment storage at the mean annual scale. There is a general pattern that the catchments with a larger snow ratio have higher runoff index for a given dryness index, which is consistent with the finding from data set in the USA (Berghuijs et al., 2014). However, it is still not clear that the different snow ratios of each catchment result in this kind of variance in runoff index. Before we can make this conclusion, effects of other factors on runoff index need to be excluded.

Due to limitation of available catchment data, as well as recent studies implying that the vegetation coverage (Donohue et al., 2007; Voepel et al., 2011; Xu et al., 2013) and average slope (Yang et al., 2009, 2014a) of catchment may be the key control on long-term hydrologic partitioning of precipitation, we assume that vegetation coverage and average slope can be thought of as two integrators of catchment properties. We estimated the specific catchment parameter $n$ in Eq. (7) from historical observations for each catchment. In order to clear away the impacts that catchment local characteristics (herein the vegetation cover and slope are thought as the proxy of integral characteristics) have on runoff, all catchments are divided into four groups, and catchments in the same group share the similar vegetation coverage or slope. Pearson's linear correlation between the specific catchment parameter $n$ and the snow ratio in the same group is calculated, by which we can tell whether the snow ratio still has a significant impact on catchment water-energy balance after getting rid of the influence of local catchment properties. Figures 3 and 4 show how specific catchment parameters vary with different snow ratios in each group with similar catchment vegetation cover and average slope, respectively. The results suggest that for those catchments with similar local catchment properties, catchments with a higher snow ratio tend to have a 

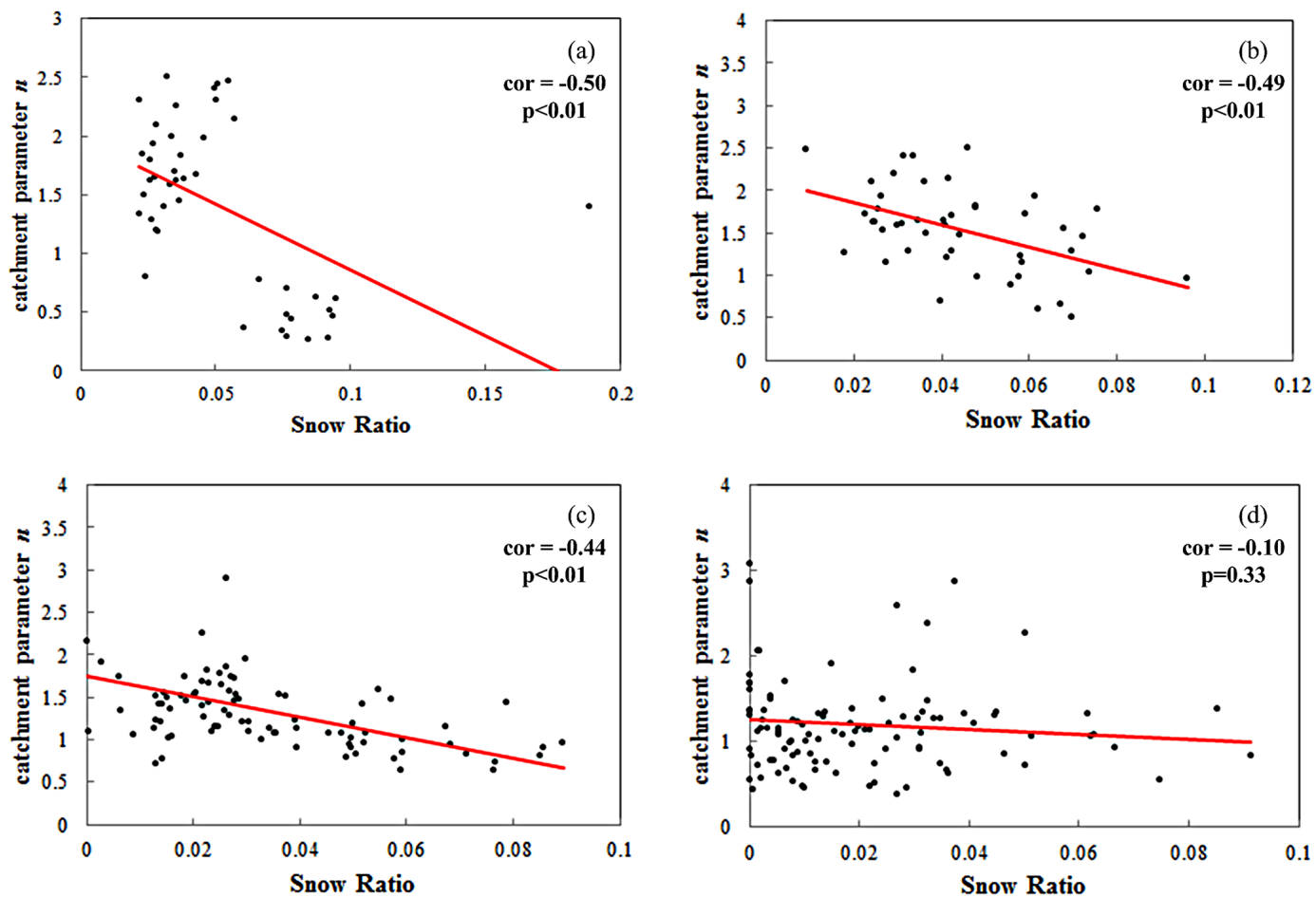

Figure 3. In the context of the Budyko-Choudhury framework, statistical relationships between the specific catchment parameter $n$ and the snow ratio, under similar vegetation coverage. Least squares regression lines are shown on each of the plots. The Pearson's linear correlation coefficient clarifies the significant negative correlation between snow ratio and catchment parameter. (a-d) indicate the vegetation coverage of $<0.3,(0.3,0.4),(0.4,0.5)$, and $>0.5$, respectively.
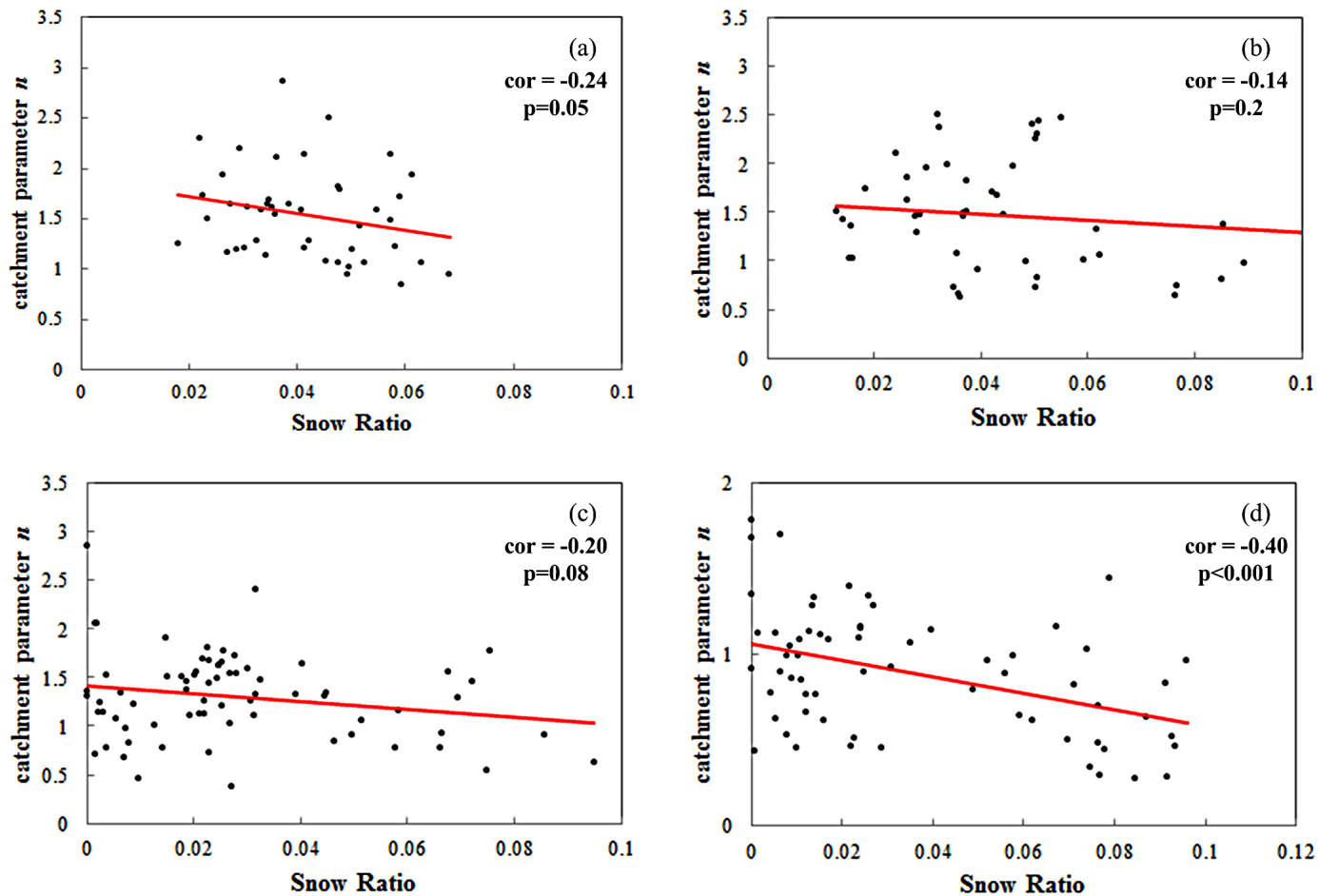

Figure 4. Similar with Fig. 3 for catchment average slope. (a-d) indicate the average slope $(\%)$ of $(0.2,3.8),(3.8,5.5),(5.5,8.0)$, and $>8.0$, respectively. 
Table 2. Summary of correlation between specific catchment parameter and snow ratio for different catchment groups $-n$ is estimated by Eq. (7); $n^{\prime}$ is estimated by Eq. (11).

\begin{tabular}{|c|c|c|c|c|c|c|}
\hline & \multicolumn{2}{|c|}{ All 282 catchments } & \multirow{2}{*}{\multicolumn{2}{|c|}{$\begin{array}{c}\text { Catchments with } \\
\qquad r_{\mathrm{S}}>0.01\end{array}$}} & \multirow{2}{*}{\multicolumn{2}{|c|}{$\begin{array}{l}\text { Catchments with } \\
\qquad r_{\mathrm{s}}>0.02\end{array}$}} \\
\hline & \multirow[b]{2}{*}{$n$} & \multirow[b]{2}{*}{$n^{\prime}$} & & & & \\
\hline & & & $n$ & $n^{\prime}$ & $n$ & $n^{\prime}$ \\
\hline As a whole & $-0.21^{* * *}$ & 0.05 & $-0.27^{* * *}$ & 0.04 & $-0.38^{* * *}$ & -0.03 \\
\hline \multicolumn{7}{|c|}{ Vegetation coverage } \\
\hline $0.1-0.3$ & $-0.50^{* * *}$ & -0.03 & $-0.50^{* * *}$ & -0.03 & $-0.50^{* * *}$ & -0.03 \\
\hline $0.3-0.4$ & $-0.49^{* * *}$ & $-0.32^{*}$ & $-0.44^{* * *}$ & -0.28 & $-0.48^{* * *}$ & $-0.32^{*}$ \\
\hline $0.4-0.5$ & $-0.44^{* * *}$ & $-0.38^{*}$ & $-0.47^{* * *}$ & $-0.36^{* *}$ & $-0.59^{* * *}$ & $-0.48^{* * *}$ \\
\hline $0.5-0.7$ & -0.09 & 0.18 & 0.03 & 0.08 & -0.04 & 0 \\
\hline \multicolumn{7}{|c|}{ Slope (\%) } \\
\hline $0.2-3.8$ & $-0.24^{*}$ & 0.01 & $-0.25^{*}$ & -0.03 & $-0.30^{* *}$ & -0.07 \\
\hline $3.8-5.5$ & -0.14 & 0.27 & -0.06 & 0.33 & -0.16 & 0.26 \\
\hline $5.5-8.0$ & -0.20 & -0.03 & $-0.35^{* * *}$ & -0.14 & $-0.41^{* * *}$ & -0.19 \\
\hline $8.0-18.7$ & $-0.40^{* * *}$ & $-0.29^{*}$ & $-0.47^{* * *}$ & $-0.36^{* *}$ & $-0.45^{* * *}$ & $-0.34^{*}$ \\
\hline
\end{tabular}

Note: ${ }^{*}{ }^{* *}$ and ${ }^{* * *}$ indicate the significant level at $0.05,0.01$ and 0.001 , respectively.

smaller specific catchment parameter $n$. Moreover, the notable negative correlation between catchment parameter $n$ and the snow ratio can be seen in the catchments under small and medium vegetation cover (Fig. 3a-c), or large average slope (Fig. 4d).

In other words, when excluding the effects of local catchment characteristics, catchments with a larger snow ratio are believed to yield more runoff under the same climatological condition. With the above analysis, we can make a more solid conclusion that the snow ratio itself indeed has impact on mean annual runoff in the context of the Budyko hypothesis. Changes in the state of precipitation from snow to rainfall not only affect the seasonal runoff dynamics but also alter the mean annual runoff amount. Accordingly, how to evaluate the effects of snow ratio on annual runoff variance is meaningful. Furthermore, quantifying the sensitivity of annual runoff to snow ratio using a new approach based on the Budyko hypothesis, instead of employing least squares estimators of historical records (Berghuijs et al., 2014), may provide more insight into this phenomenon. Therefore, much more elaboration with physic mechanism, like proposed in Sect. 3.1, is needed to build.

\subsection{Validity of the Budyko framework considering snow effects}

We estimated the catchment parameter $n^{\prime}$ in Eq. (11), and then evaluated the method's validity by investigating the relationship between $n^{\prime}$ and snow ratio. As shown in Table 2, the correlation between $n^{\prime}$ value and snow ratio for each catchment was calculated. The correlation approximates to zero and is insignificant, when taking all 282 catchments as a whole. Furthermore, when catchments are grouped by vegetation coverage as in Sect. 4.1, no significant negative correlation is detected, except for group with vegetation coverage of 0.4-0.5, and the findings are similar for catchment groups classified by slope.

Actually, we intend to analyze the long-term water balance of catchment where snow plays a considerable role in hydrological process. Thus, it may be better to investigate the validity of the proposed method by excluding the results from where there is little snow. Afterwards, we further calculate the corresponding correlation for catchments with a snow ratio larger than 0.01 and 0.02 . Among these catchments, a more significant negative correlation between $n$ estimated by Eq. (7) and the snow ratio can be seen, and the correlation coefficients are generally larger in catchments with a snow ratio of 0.02 , implying the obvious effect of snow ratio on runoff there. Overall, the correlations between $n^{\prime}$ estimated by Eq. (11) and the snow ratio tend to be insignificant. It therefore indicates that Eq. (11) has a good performance for evaluating the impact of the snow ratio on mean annual runoff.

\subsection{Contribution of climate and land use change to runoff}

The annual runoff experiences a downward (decreasing) step change across China around 1980 (Zhang et al., 2008). The change in mean annual runoff is calculated as the difference between the period of 1980-2005 and the period of 19561979. As shown in Fig. 5, most of the study catchments show a decreasing runoff change rate, defined as the ratio of runoff change between two periods to mean annual runoff. 


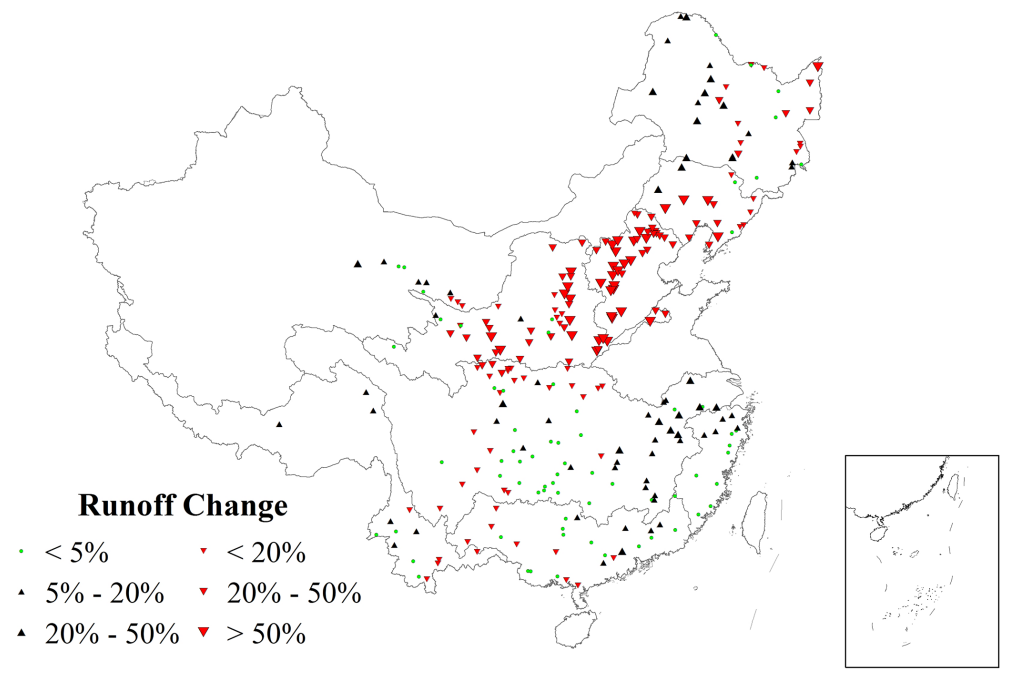

Figure 5. Mean annual runoff change rate between two periods.

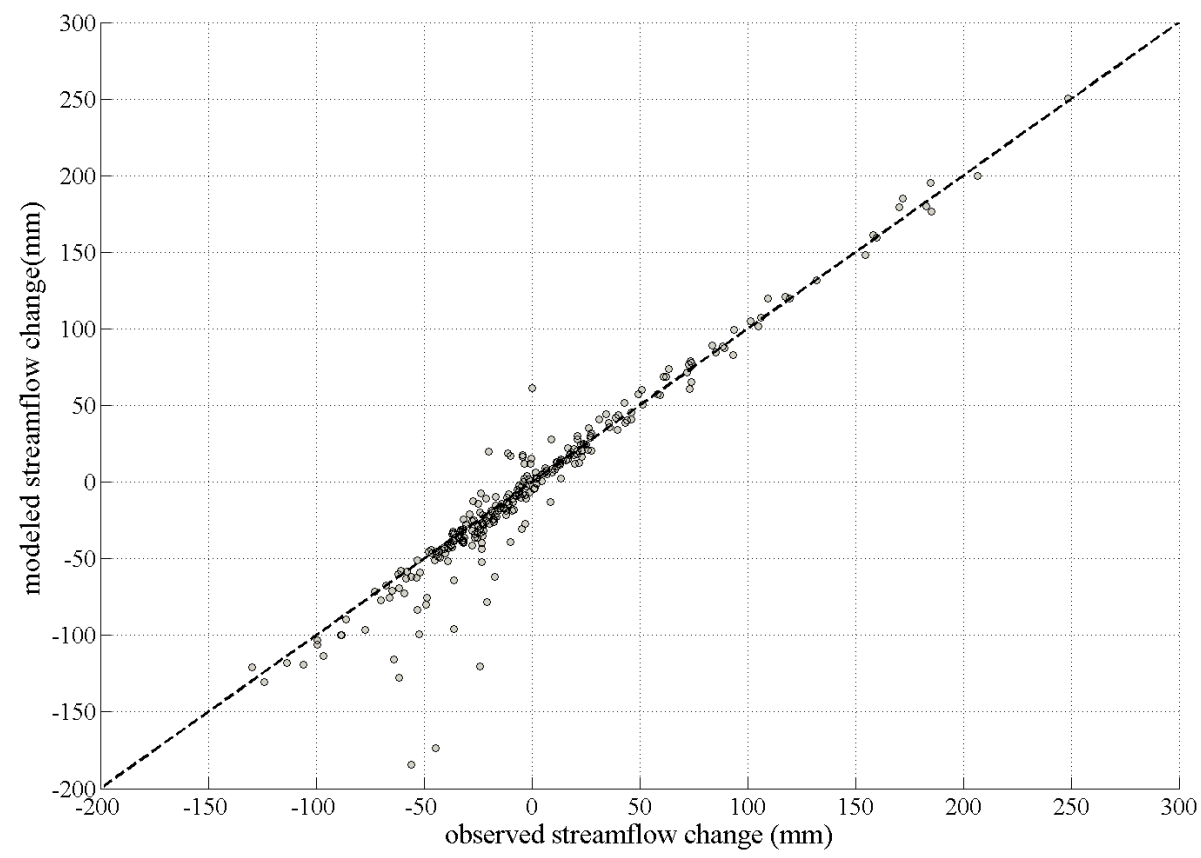

Figure 6. Comparison between observed and calculated mean annual runoff change.

The modeled runoff change is calculated by Eq (13). Figure 6 shows the comparison between modeled runoff changes and that observed for all 282 catchments. The points scatter overall along with the $1: 1$ line, indicating the proposed attribution method has a good performance for most catchments and it is convincing to analyze the relative contribution of each variable to mean annual runoff variation using this method.

The relative contributions of four factor variations to the annual runoff change are depicted in Fig. 7. During the past 50 years, total precipitation amount across China has no obvious trend, while increasing winter precipitation is seen in parts of the northern high latitude and mountains (Sun et al., 2010; Zhang and Cong, 2014). As a result, it is obvious that a significant effect of change in the snow ratio on annual runoff alteration is found in northwestern mountainous and highlatitude catchments (Fig. 7a) where a larger portion of winter precipitation falls in a solid state. Generally, the increasing snow ratio makes a negative contribution to the observed decreasing mean annual runoff; there is no general spatial pattern where change in total precipitation has a remarkable contribution to annual runoff alteration (Fig. 7b). During the past 3 decades, northern China, especially the North China 


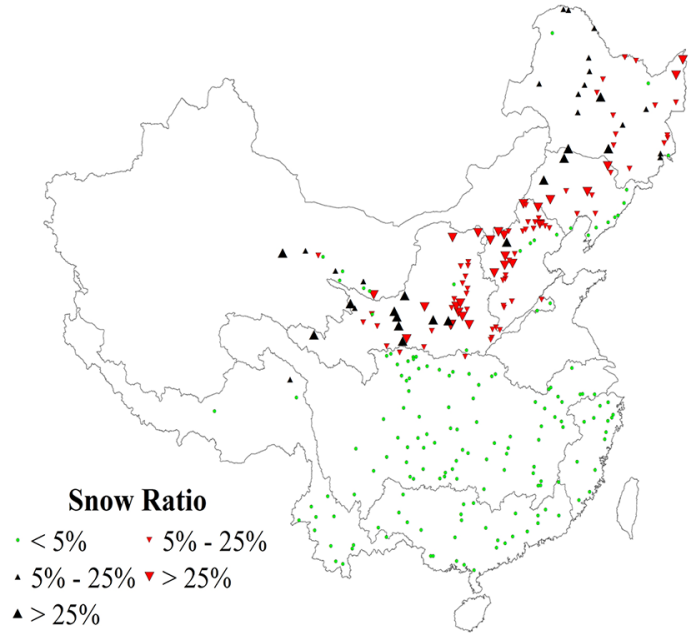

(a)

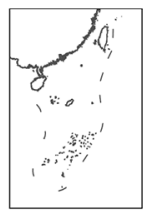

(c)

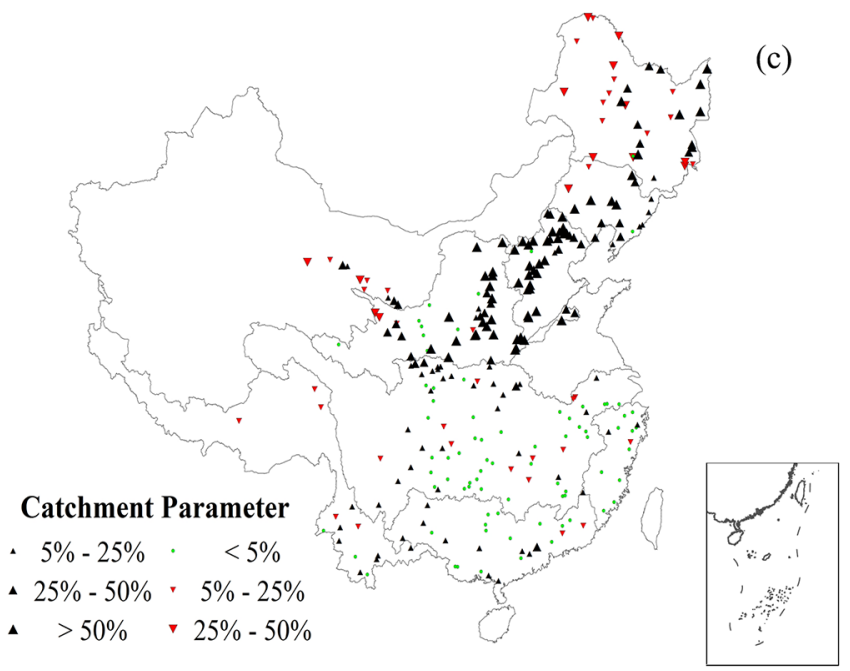

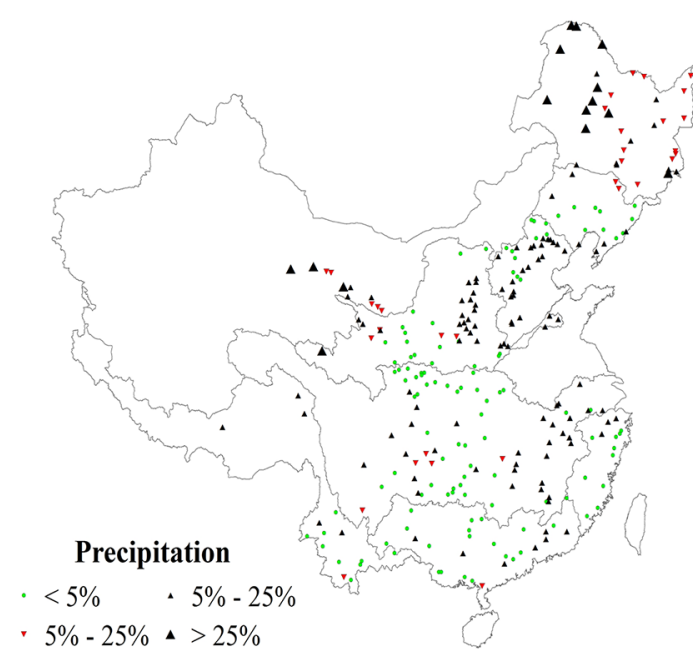

(b)

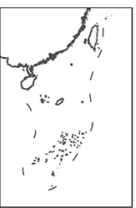

(d)

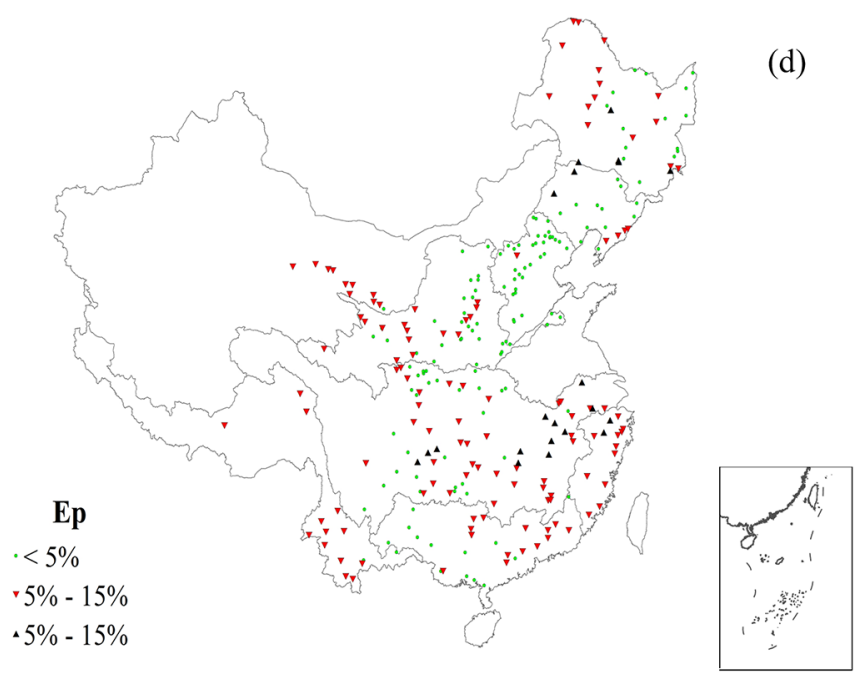

Figure 7. Relative contributions of (a) snow ratio, (b) precipitation, (c) specific catchment parameter, and (d) potential evapotranspiration variance to change in mean annual runoff. Upward triangle represents the positive relative contribution of the variable to change in runoff, while downward triangle represents the negative.

Plain (Liu et al., 2003), has been seeing significant land use and land cover change, including urbanization and afforestation. Therefore, a large difference of catchment property $n$ between two studied periods is expected. Among the four variables, the catchment parameter (Fig. 7c) has most significant effects on mean annual runoff change. In most parts of China, the annual $E_{\mathrm{p}}$ shows a decreasing trend, but the decreasing magnitude between post- and pre-period is negligible (Gao et al., 2006). As expected, the overall small negative $(<15 \%)$ or tiny relative contribution of decreasing $E_{\mathrm{p}}$ to decreasing mean annual runoff is shown in Fig. $7 \mathrm{~d}$.

\subsection{Plausible future runoff changes}

As far as we are concerned, in a plausible future warming climate, quantifying the change in annual runoff resulting from per unit variation in the fraction of precipitation falling as snow is particularly vital for water resources planning. An insight into possible influence of future changing climate, especially snow ratio on annual runoff, is provided here. The 2050-2099 average annual precipitation, snow ratio and $E_{\mathrm{p}}$ of each catchment estimated from the multi-model ensemble average values are used as climate forcing to calculate corresponding catchment's future mean annual runoff by Eq. (11), assuming unchanged catchment parameter $n^{\prime}$ estimated from the past-decade observed data.

The projected mean annual runoff increase for 20502099 relative to $1956-2005$ is widespread in northern China (Fig. 8). On the other hand, a slight decrease is projected in most regions of southern China. The spatial pattern of the projected runoff change is consistent with runoff outputs from atmosphere-ocean general circulation models participating in the CMIP5 (Koirala et al., 2014). The runoff increase projection in parts of northern China mainly results 

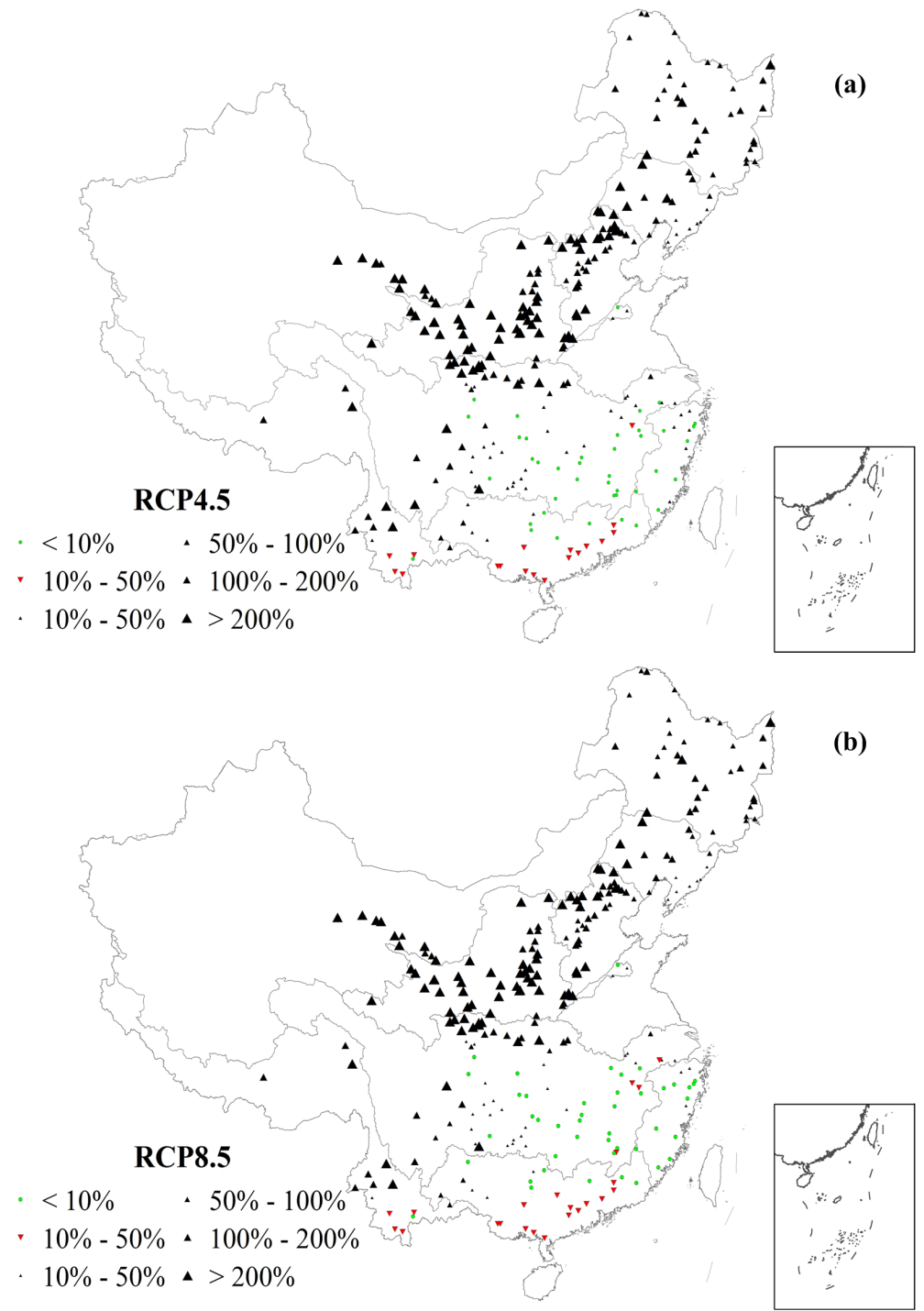

Figure 8. Change rate of mean annual runoff under projected future climate. (a) RCP4.5 and (b) RCP8.5.

from future increasing precipitation amount, as well as the increasing snowfall, which is also reported by other climate change impact assessments in East Asia (Immerzeel et al., 2013). As shown in Fig. 9, the contribution of snow ratio to runoff change, defined as the ratio of runoff change due to snow ratio change to the total runoff change, is overall positive and pronounced over the catchments located in northern high-latitude and northwestern mountainous regions. The regions are consistent with areas where catchment runoff is sensitive to snow ratio variation over the past several decades as shown in Fig. 7a. Moreover, the patterns of snow ratio's contribution to runoff for RCP4.5 and RCP8.5 scenarios bear some overall resemblance, including the sensitive areas and magnitudes. Also, some differences exist where snow ratio change contributes more to runoff increasing for RCP4.5 than RCP8.5, mainly in central China. Specifically, the snow ratio's contribution to runoff change for RCP4.5 is overall larger than that for RCP8.5, although the differences are insignificant (Fig. 10). It indicates that simulated climate outputs forced with a mid-range mitigation emissions scenario (RCP4.5) tend to more runoff and larger snow ratio's contribution to runoff change in China, compared with that under a high-emissions scenario.

\subsection{Error analysis of attribution method}

Since only the first-order approximation of runoff change is used to calculate the contribution of each variable in the attribution method Eq. (13), we conduct the error analysis to access its performance in the following. Similar with Yang et al. (2014a), the Taylor series of Eq. (12) is employed to show the complete expression of runoff change as 

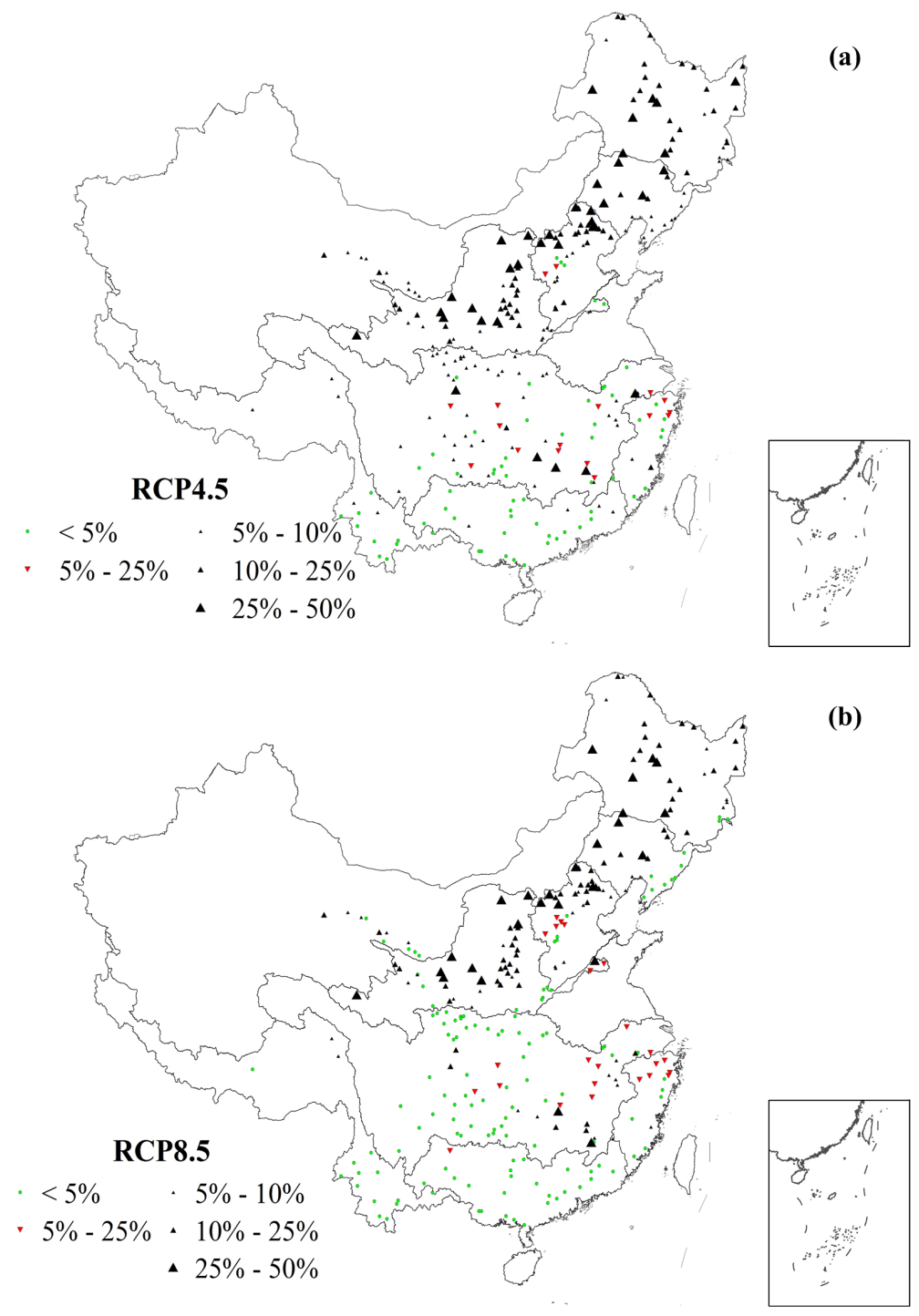

Figure 9. Contribution of snow ratio variance to change in mean annual runoff under projected future climate. (a) RCP4.5 and (b) RCP8.5.

$Q\left(P_{1}+\Delta P_{1}, E_{\mathrm{p} 1}+\Delta E_{\mathrm{p} 1}, r_{\mathrm{s} 1}+\Delta r_{\mathrm{s} 1}, n_{1}+\Delta n_{1}\right)$

$=Q\left(P_{1}, E_{\mathrm{p} 1}, r_{\mathrm{s} 1}, n_{1}\right)+\left(\Delta P_{1} \frac{\partial}{\partial P_{1}}+\Delta E_{\mathrm{p} 1} \frac{\partial}{\partial E_{\mathrm{p} 1}}\right.$

$\left.+\Delta r_{\mathrm{s} 1} \frac{\partial}{\partial r_{\mathrm{s} 1}}+\Delta n_{1} \frac{\partial}{\partial n_{1}}\right) Q\left(P_{1}, E_{\mathrm{p} 1}, r_{\mathrm{s} 1}, n_{1}\right)$

$+\frac{1}{2 !}\left(\Delta P_{1} \frac{\partial}{\partial P_{1}}+\Delta E_{\mathrm{p} 1} \frac{\partial}{\partial E_{\mathrm{p} 1}}+\Delta r_{\mathrm{s} 1} \frac{\partial}{\partial r_{\mathrm{s} 1}}+\Delta n_{1} \frac{\partial}{\partial n_{1}}\right)^{2}$

$Q\left(P_{1}, E_{\mathrm{p} 1}, r_{\mathrm{s} 1}, n_{1}\right)+\cdots$.

The runoff change induced by the snow ratio change can be expressed as

$$
\begin{aligned}
& \Delta Q_{\Delta r_{\mathrm{s}}}=\Delta r_{\mathrm{s} 1} \frac{\partial}{\partial r_{\mathrm{s} 1}} Q\left(P_{1}, E_{\mathrm{p} 1}, r_{\mathrm{s} 1}, n_{1}\right) \\
& +\frac{1}{2 !}\left(\Delta r_{\mathrm{s} 1} \frac{\partial}{\partial r_{\mathrm{s} 1}}+\Delta P_{1} \frac{\partial}{\partial P_{1}}+\Delta E_{\mathrm{p} 1} \frac{\partial}{\partial E_{\mathrm{p} 1}}+\Delta n_{1} \frac{\partial}{\partial n_{1}}\right) \\
& \Delta r_{\mathrm{s} 1} \frac{\partial}{\partial r_{\mathrm{s} 1}} Q\left(P_{1}, E_{\mathrm{p} 1}, r_{\mathrm{s} 1}, n_{1}\right),
\end{aligned}
$$

where we neglect the third- and higher-order terms of Eq. (16) for the third order is equal to $3 \%$ of the second order according to Yang et al. (2014b). The relative error (RE) of attribution method to investigate the contribution of snow ratio change is estimated as

$\mathrm{RE}_{\Delta r_{\mathrm{s}}}=\left|\Delta Q_{\Delta r_{\mathrm{s}}}-\Delta Q_{r_{\mathrm{s}}}\right| /\left|\Delta Q_{\Delta r_{\mathrm{s}}}\right|$.

As shown in Fig. 11, the relative errors of attribution method with respect to snow ratio change are small for all 282 catchments. Specifically, as for the contribution of snow ratio 


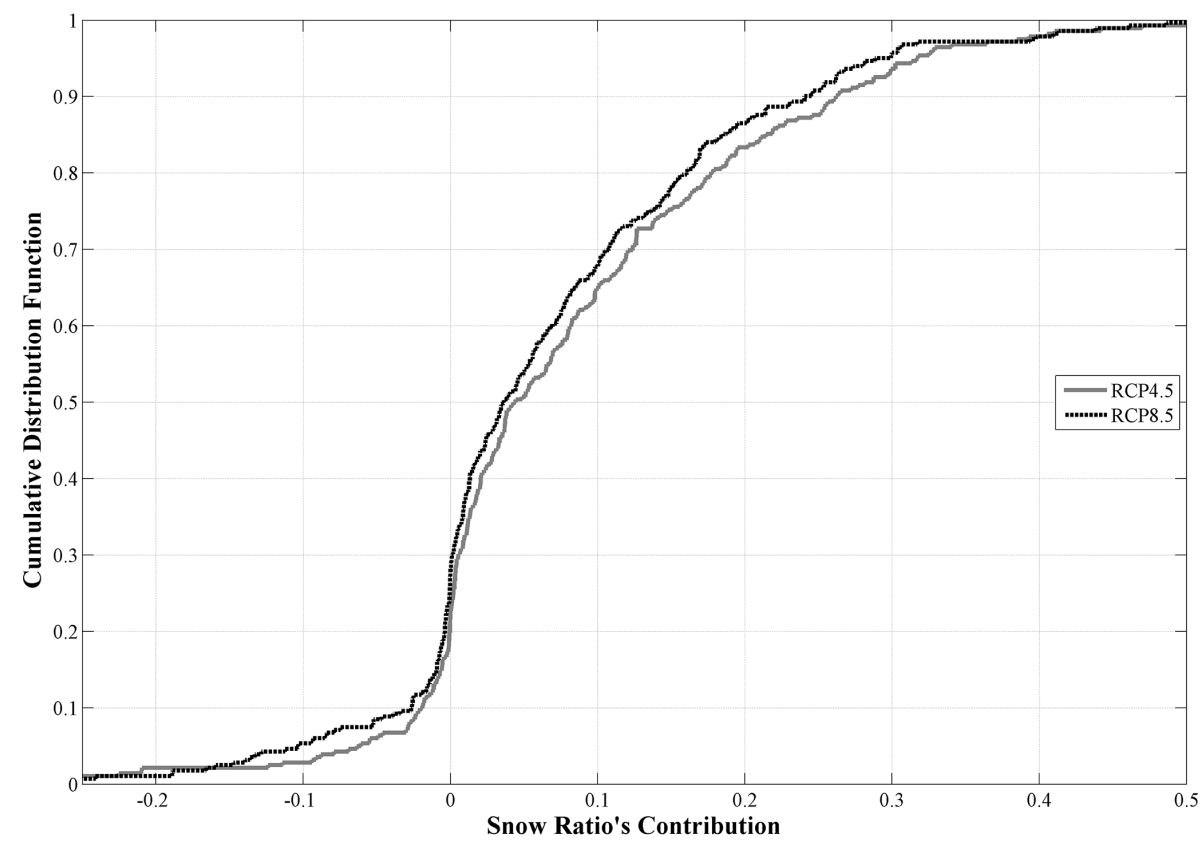

Figure 10. Cumulative distribution function of snow ratio's contribution to runoff change under projected future climate.

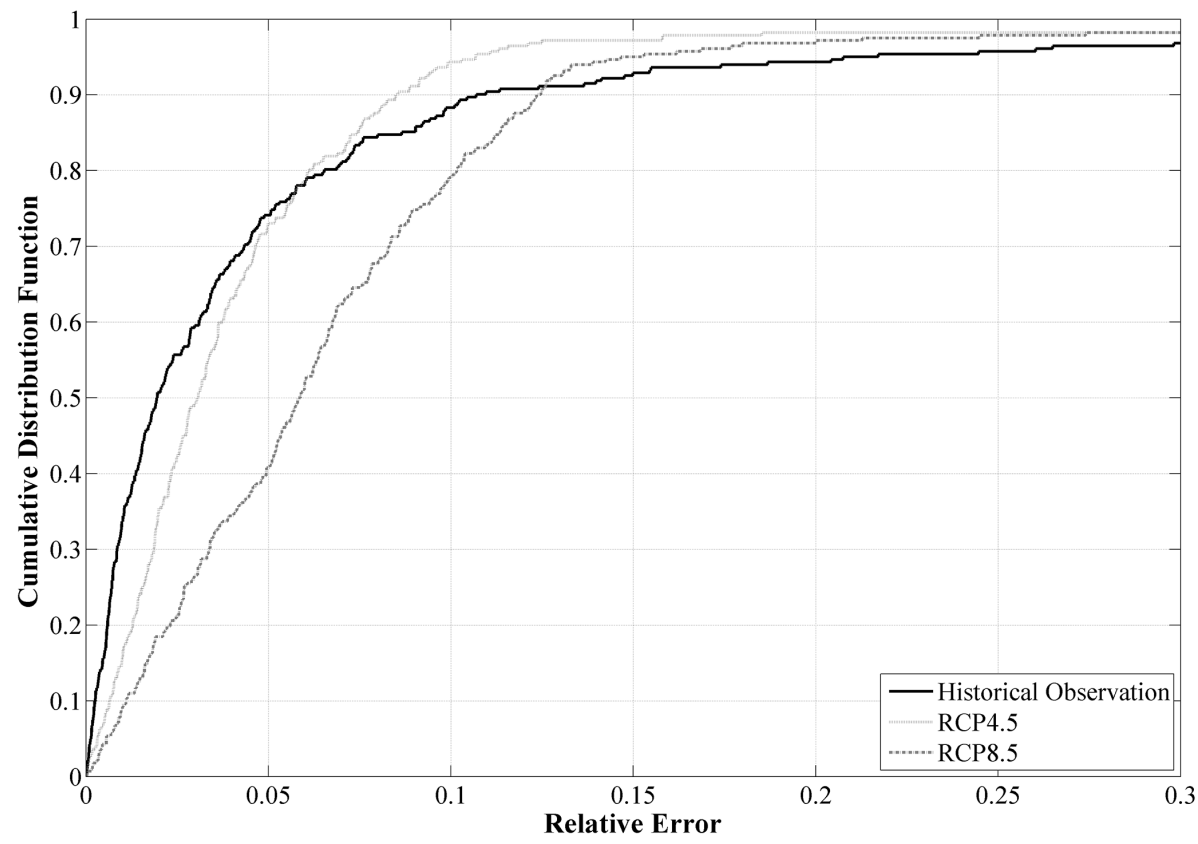

Figure 11. Cumulative distribution function of the relative error of attribution method in three cases.

change to the historical runoff, the RE of more than $90 \%$ of catchments is no more than $11 \%$. As to the two projected future climate change scenarios, the REs of more than $90 \%$ of catchments are less than 8 and $12 \%$ for RCP 4.5 and RCP8.5, respectively. Therefore, the proposed first-order approximation attribution method is reliable.

\subsection{Limitation of revised Budyko framework}

It should be noted that the assumption of no evapotranspiration loss in snowmelt adopted in Sect. 3.1 is not universally applicable. In small catchments, after snowfall is melt and the concrete frozen ground inhibits snowmelt infiltration, the snow water can flow away quickly though channels without evaporation loss. However, if the location of 
accumulated snow is far away from channels, or the snowfall amount is large, it will take longer for meltwater to run off than the frozen soil thaws. In these cases, a part of snow infiltrates into the ground and later is available for evaporation (Dripps, 2012; Jasechko et al., 2014). In fact, it may be more suitable to introduce as effective available water for evapotranspiration, where $k$ is a loss parameter requiring further investigation. To better understand and parameterize the snowmelt loss by evapotranspiration, the site-specific modeling and isotope-based field observations may provide tools for more detailed modeling in the future.

Apart from limitation of the assumption, the accurate estimation of snow ratio is also important for this framework. However, direct snow observation records are not available for the case study watersheds in this manuscript and the MOPEX watersheds used by Berguhijs et al. (2014). Mean annual snowfall is estimated by the air temperature-based empirical method. The threshold temperature is critical for calculating the snowfall amount. A higher threshold temperature will overestimate the snow ratio that may lead to an unreasonable conclusion under the framework in our study. According to the sensitivity analysis of catchment parameter estimation, it shows that a small variation in snow ratio can lead to a significant change in catchment parameter when snow ratio is large enough to be comparable to runoff index. Thus, the accuracy of snow ratio is important to this framework especially when the snow ratio is large, which limits the applicability of this framework in those catchments.

\section{Conclusions}

In this study, we showed that the snow ratio could have a pronounced effect on mean annual runoff based on both historical records and theoretical analysis. In the context of the Budyko hypothesis, catchments with a larger snow ratio tend to yield more long-term mean annual runoff given the same other climatological and landscape properties. Moreover, a Budyko-type equation considering the water-energy balance is derived to quantify the effects of snow ratio on runoff. With the assistance of the proposed relationship, the contribution of snow ratio to change in annual runoff during the past 5 decades and potential annual runoff variation due to changing fraction of precipitation falling as snow under a projected future global warming scenario in China are investigated. The results indicate that those sensitive catchments in northwestern mountainous and north-central high-latitude areas are undergoing remarkable runoff change resulting from snow ratio variance. In addition, the error analysis of attribution method is conducted, implying that the first-order approximation is suitable to assess the contribution of snow ratio change to runoff in this study.

This paper extends the previous work that suggested that precipitation shift from snow towards rain leads to a decrease in runoff based on a data set in USA (Berghuijs et al., 2014).
We confirm here that the observations in China give a similar conclusion. Furthermore, we quantify this effect and assess the impact of climate change, especially snow ratio change, on mean annual runoff across China. As major rivers originating from mountainous regions where temperature determines the state of precipitation (Allamano et al., 2009) and afterwards affects annual runoff amount as discussed above, the findings here have valuable implications for future water management policy. The proposed model can be made applicable to other mountainous catchments of the world easily and quantify the effects of possible change in the snow ratio on available water resources and analyze the vulnerability of catchments to climate change.

Acknowledgements. This research was funded in part under the National Science Foundation of China grants 91225302 and 51179083. The GCM data can be downloaded at http://cmip-pcmdi.llnl.gov/cmip5. We thank D. Wang, W. R. Berghuijs and anonymous reviewer whose constructive comments and feedbacks help improve this paper considerably.

Edited by: D. Wang

\section{References}

Allamano, P., Claps, P., and Laio, F.: Global warming increases flood risk in mountainous areas, Geophys. Res. Lett., 36, L24404, doi:10.1029/2009GL041395, 2009.

Allen, R. G., Pereira, L. S., Raes, D., and Smith, M.: Crop evapotranspiration-Guidelines for computing crop water requirements, FAO Irrigation and drainage paper 56, FAO, Rome, Italy, 1998.

Anderson, E. A.: Development and testing of snow pack energy balance equations, Water Resour. Res., 4, 19-37, 1968.

Anderson, E. A.: A point energy and mass balance model of a snow cover, US National Oceanic and Atmospheric Administration NOAA Technical Report NWS 19, US National Oceanic and Atmospheric Administration NOAA, Silver Spring, MD, 1976.

Barnett, T. P., Adam, J. C., and Lettenmaier, D. P.: Potential impacts of a warming climate on water availability in snow-dominated regions, Nature, 438, 303-309, 2005.

Berghuijs, W. R., Woods, R. A., and Hrachowitz, M.: A precipitation shift from snow towards rain leads to a decrease in runoff, Nat. Clim. Change, 4, 583-586, 2014.

Budyko, M. I.: Climate and Life, Academic Press, New York, 1974. Buermann, W., Wang, Y., Dong, J., Zhou, L., Zeng, X., Dickinson, R. E., Potter, C. S., and Myneni, R. B.: Analysis of a multiyear global vegetation leaf area index data set, J. Geophys. Res.Atmos., 107, 4646-4646, 2002.

Cayan, D. R., Maurer, E. P., Dettinger, M. D., Tyree, M., and Hayhoe, K.: Climate change scenarios for the California region, Climatic Change, 87, 21-42, 2008.

Choudhury, B.: Evaluation of an empirical equation for annual evaporation using field observations and results from a biophysical model, J. Hydrol., 216, 99-110, 1999. 
Dewalle, D. R. and Meiman, J. R.: Energy exchange and late season snowmelt in a small opening in Colorado subalpine forest, Water Resour. Res., 7, 184-188, 1971.

Ding, B., Yang, K., Qin, J., Wang, L., Chen, Y., and He, X.: The dependence of precipitation types on surface elevation and meteorological conditions and its parameterization, J. Hydrol., 513, 154-163, 2014.

Dingman, S. L.: Physical hydrology, Prentice Hall, Englewood Cliffs, NJ, 2002.

Donohue, R. J., Roderick, M. L., and McVicar, T. R.: On the importance of including vegetation dynamics in Budyko's hydrological model, Hydrol. Earth Syst. Sci., 11, 983-995, doi:10.5194/hess11-983-2007, 2007.

Dripps, W R.: An integrated field assessment of groundwater recharge, Open Hydrology Journal, 6, 15-22, 2012.

Dunne, T. and Black, R. D.: Runoff Processes during Snowmelt, Water Resour. Res., 7, 1160-1172, doi:10.1029/WR007i005p01160, 1971.

Fahey, T. J. and Lang, G. E.: Concrete frost along an elevational gradient in New Hampshire, Can. J. Forest Res., 5, 700-705, 1975.

Feng, X., Vico, G., and Porporato, A.: On the effects of seasonality on soil water balance and plant growth, Water Resour. Res., 48, W05543, doi:10.1029/2011WR011263, 2012.

$\mathrm{Fu}$, B. P.: On the calculation of the evaporation from land surface, Scient. Atmos. Sin., 5, 23-31, 1981 (in Chinese).

Gao, G., Chen, D., Ren, G., Chen, Y., and Liao, Y.: Spatial and temporal variations and controlling factors of potential evapotranspiration in China: 1956-2000, J. Geogr. Sci., 16, 3-12, 2006.

Godsey, S. E., Kirchner, J. W., and Tague, C. L.: Effects of changes in winter snowpacks on summer low flows: case studies in the Sierra Nevada, California, USA, Hydrol. Process., 28, 50485064, doi:10.1002/hyp.9943, 2014.

Gutman, G. and Ignatov, A.: The derivation of the green vegetation fraction from NOAA/AVHRR data for use in numerical weather prediction models, Int. J. Remote Sens., 19, 1533-1543, 1998.

Hamon, W. R.: Estimating potential evapotranspiration, J. Hydraul. Div. Proc. Am. Soc. Civil Eng., 87, 107-120, 1961.

Huss, M., Farinotti, D., Bauder, A., and Funk, M.: Modelling runoff from highly glacierized alpine drainage basins in a changing climate, Hydrol. Process., 22, 3888-3902, 2008.

Immerzeel, W. W., Pellicciotti, F., and Bierkens, M. F. P.: Rising river flows throughout the twenty-first century in two Himalayan glacierized watersheds, Nat. Geosci., 5, 841-842, 2013.

Jasechko, S., Birks, S. J., Gleeson, T., Wada, Y., Fawcett, P. J., Sharp, Z. D., McDonnell, J. J., and Welker, J. M.: The pronounced seasonality of global groundwater recharge, Water Resour. Res., 50, 8845-8867, doi:10.1002/2014WR015809, 2014.

Koirala, S., Hirabayashi, Y., Mahendran, R., and Kanae, S.: Global assessment of agreement among streamflow projections using CMIP5 model outputs, Environ. Res. Lett., 9, 064017, doi:10.1088/1748-9326/9/6/064017, 2014.

Liu, J., Liu, M., Zhuang, D., Zhang, Z., and Deng, X.: Study on spatial pattern of land-use change in China during 1995-2000, Sci. China Ser. D, 46, 373-384, 2003.

Payne, J. T., Wood, A. W., Hamlet, A. F., Palmer, R. N., and Lettenmaier, D. P.: Mitigating effects of climate change on the water resources of the Columbia River Basin, Climatic Change, 62, 233-256, 2004.
Pierce, R. S., Lull, H. W., and Storey, H. C.: Influence of land use and forest condition on soil freezing and snow depth, Forest Sci., 4, 246-263, 1958.

Roderick, M. L. and Farquhar, G. D.: A simple framework for relating variations in runoff to variations in climatic conditions and catchment properties, Water Resour. Res., 47, W00G07, doi:10.1029/2010WR009826, 2011.

Stewart, I. T., Cayan, D. R., and Dettinger, M. D.: Changes toward earlier streamflow timing across western North America, J. Climate, 18, 1136-1155, 2005.

Sun, X., Sun, Z., and Luo, Y.: Characteristics of snowfall from 1960 to 2005 in northeast China, J. Meteorol. Environ., 1, 1-5, 2010 (in Chinese).

Taylor, K. E., Stouffer, R. J., and Meehl, G. A.: An Overview of CMIP5 and the experiment design, B. Am. Meteorol. Soc., 93 , 485-498, 2012.

Voepel, H., Ruddell, B., Schumer, R., Troch, P. A., Brooks, P. D., Neal, A., Durci, M., and Sivapalan, M.: Quantifying the role of climate and landscape characteristics on hydrologic partitioning and vegetation response, Water Resour. Res., 47, W00J09, doi:10.1029/2010WR009944, 2011.

Vörösmarty, C. J., Sharma, K. P., Fekete, B. M., Copeland, A. H., Holden, J., Marble, J., and Lough, J. A.: The storage and aging of continental runoff in large reservoir systems of the world, Ambio, 26, 210-219, 1997.

Wang, D. and Hejazi, M.: Quantifying the relative contribution of the climate and direct human impacts on mean annual streamflow in the contiguous United States, Water Resour. Res., 47, W00J12, doi:10.1029/2010WR010283, 2011.

Wang, D. and Tang, Y.: A one-parameter Budyko model for water balance captures emergent behavior in darwinian hydrologic models, Geophys. Res. Lett., 41, 4569-4577, doi:10.1002/2014GL060509, 2014.

Weller, G. and Holmgren, B.: The microclimates of the arctic tundra, J. Appl. Meteorol., 13, 854-862, 1974.

Xu, X., Liu, W., Scanlon, B. R., Zhang, L., and Pan, M.: Local and global factors controlling water-energy balances within the Budyko framework, Geophys. Res. Lett., 40, 6123-6129, doi:10.1002/2013GL058324, 2013.

Yang, D., Shao, W., Yeh, P. J. F., Yang, H., Kanae, S., and Oki, T.: Impact of vegetation coverage on regional water balance in the nonhumid regions of China, Water Resour. Res., 45, W00A14, doi:10.1029/2008WR006948, 2009.

Yang, H., Yang, D., Lei, Z., and Sun, F.: New analytical derivation of the mean annual water-energy balance equation, Water Resour. Res., 44, W03410, doi:10.1029/2007WR006135, 2008.

Yang, H., Qi, J., Xu, X., Yang, D., and Lv, H.: The regional variation in climate elasticity and climate contribution to runoff across China, J. Hydrol., 517, 607-615, 2014a.

Yang, H., Yang, D., and $\mathrm{Hu}, \mathrm{Q}$. : An error analysis of the Budyko hypothesis for assessing the contribution of climate change to runoff, Water Resour. Res., 50, 9620-9629, doi:10.1002/2014WR015451, 2014b.

Zhang, J., Wang, J., Li, Y., and Zhang, S.: Study on runoff trends of the main rivers in China in the recent 50 years, China Water Res., 2, 31-34, 2008 (in Chinese). 
Zhang, L., Dawes, W. R., and Walker, G. R.: Response of mean annual evapotranspiration to vegetation changes at catchment scale, Water Resour. Res., 37, 701-708, doi:10.1029/2000WR900325, 2001.
Zhang, X. and Cong, Z.: Trends of precipitation intensity and frequency in hydrological regions of China from 1956 to 2005, Global Planet. Change, 117, 40-51, 2014. 